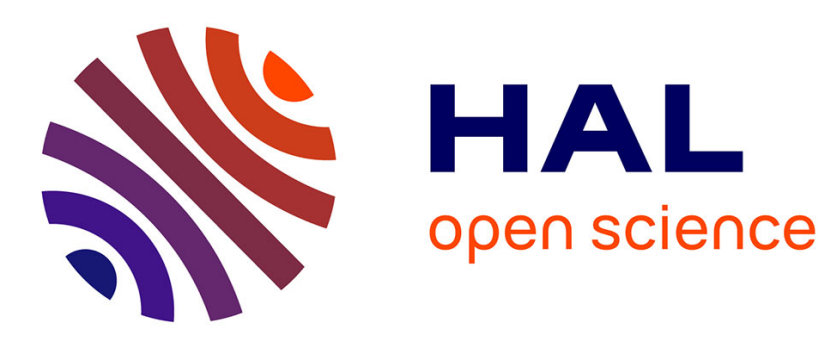

\title{
Fusarium toxins and total fungal biomass indicators in naturally contaminated wheat samples from north-eastern Poland in 2003
}

Juliusz Perkowski, Marian Wiwart, Maciej Buśko, Magdalena Laskowska, Franz Berthiller, Wolfgang Kandler, Rudolf Krska

\section{To cite this version:}

Juliusz Perkowski, Marian Wiwart, Maciej Buśko, Magdalena Laskowska, Franz Berthiller, et al.. Fusarium toxins and total fungal biomass indicators in naturally contaminated wheat samples from north-eastern Poland in 2003. Food Additives and Contaminants, 2007, 24 (11), pp.1292-1298. 10.1080/02652030701416566 . hal-00577463

\section{HAL Id: hal-00577463 \\ https://hal.science/hal-00577463}

Submitted on 17 Mar 2011

HAL is a multi-disciplinary open access archive for the deposit and dissemination of scientific research documents, whether they are published or not. The documents may come from teaching and research institutions in France or abroad, or from public or private research centers.
L'archive ouverte pluridisciplinaire HAL, est destinée au dépôt et à la diffusion de documents scientifiques de niveau recherche, publiés ou non, émanant des établissements d'enseignement et de recherche français ou étrangers, des laboratoires publics ou privés. 


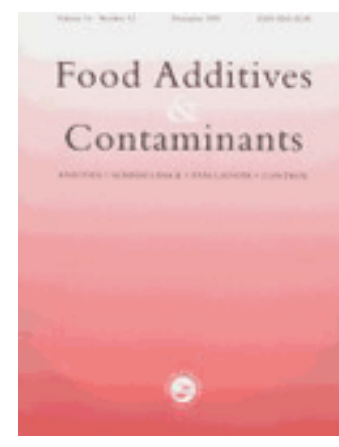

Fusarium toxins and total fungal biomass indicators in naturally contaminated wheat samples from north-eastern Poland in 2003

\begin{tabular}{|r|l|}
\hline Journal: & Food Additives and Contaminants \\
\hline Manuscript ID: & TFAC-2006-367.R1 \\
\hline Manuscript Type: & Original Research Paper \\
\hline Methods/Techniques: & Chromatography - GC/MS, Chromatography - LC/MS \\
\hline Additives/Contaminants: & Ergosterol, ATP, Mycotoxins - trichothecenes, Volatiles \\
\hline Food Types: & Wheat, Cereals and grain \\
\hline &
\end{tabular}

\section{SCHOLARONE Manuscripts}




\begin{abstract}
Concentrations of fungal metabolites were measured in 32 wheat grain samples from northeastern Poland in 2003. The samples originated from fields cultivated conventionally (but varying in chemical protection level) or cultivated organically. Concentrations of Fusarium toxins (HT-2, DON, 3-AcDON, NIV), trichodiene, microbial biomass indicators [fungal ergosterol and general adenosine-5' - triphosphate (ATP)] and seed vigour were assessed. A large variation between samples was observed, depending on their origin. Seed from organic farms contained similar amounts of Fusarium toxins but more ergosterol and ATP than conventionally grown and chemically protected seed. The highest levels of toxins and ergosterol were detected in samples from conventional cultivation lacking chemical protection. Intensive agronomic practices (including complete chemical protection) significantly lowered the levels of ergosterol, ATP and trichodiene, as compared with other cultivation systems.
\end{abstract}

Keywords: wheat, cultivation systems, trichothecenes, ergosterol, trichodiene, ATP

\title{
Introduction
}

In Poland, as in other EU countries, various fungal diseases affect wheat, but special attention is paid to Fusarium head blight (FHB). In the literature there is a shortage of convincing data about the influence of cultivation systems on the severity of its disease symptoms (Teich 1989, Champeil et al. 2004, Lemmens et al. 2004, Perkowski et al. 2004). In north-eastern Poland, organic farming is particularly important because of the low level of environmental contamination and the possibility of growing healthy food (Grodzińska et al. 1999, Łukanowski and Sadowski 2002). Literature data reporting contamination by fungal metabolites of organically grown cereals are contradictory (Elmholta and Labouriau 2005, Pussemier et al. 2006). However, some authors point to the significant influence of 
environmental conditions (weather in particular) on their concentrations. Malmauret et al. (2002) reported that concentrations of Fusarium toxins were higher in wheat and barley seed from organic farms, but their results showed no conclusive evidence whether conventional products were more or less safe than organic ones. Apart from Fusarium toxins, also fungal biomass in seed is important. Fungal biomass is usually estimated on the basis of ergosterol or chitin content (Abramson et al. 1998, Ekblad et al. 1998). Also ATP level is measured on the surface of kernels, because it is correlated with levels of some other fungal metabolites (Williams 1989), but it reflects the level of the whole microbial biomass. Seed colonization by fungi often affects its vigour and consequently also sowing value. Infection by pathogens of the genus Fusarium often disturbs or even completely inhibits seed germination (Eudes et al. 1997, Packa and Koczowska 1987).

This study was aimed to compare concentrations of fungal metabolites in wheat seed from conventional farms (with more or less intensive use of chemical protection) and organic farms. The comparison involved a complex of fungal metabolites: concentrations of selected Fusarium toxins (deoxynivalenol, 3-acetyldeoxynivalenol, the sum of 3-acetyldeoxynivalenol and 15-acetyldeoxynivalenol, nivalenol, fusarenon-X, diacetoxyscirpenol, HT-2 toxin, T-2 toxin and zearalenone), trichodiene (their precursor), and microbial biomass indicators (fungal ergosterol and general microbial ATP). Differences in the studied characters between four cultivation systems and correlations between concentrations of the studied metabolites were analysed.

\section{Material and methods}

\section{Samples}

The analysis involved 32 grain samples (of $1000 \mathrm{~g}$ each) of winter and spring wheat from conventional farms (20 samples) and organic farms (12 samples) located in 7 districts in north-western Poland (Figure 1). Conventional farms were divided into 3 groups: CON I, CON II and CON III. In CON I (9 samples from 6 districts), complete antifungal protection and pesticides were applied. CON II (6 samples from 6 districts) included large fields (over $30 \mathrm{ha}$ ) subject to a lower level of chemical protection (fungicidal protection against main foliar diseases, first of all mildew and leaf septoriosis), while CON III (5 samples from one district Ostróda) was an experimental farm Bałcyny, where neither fungicides nor pesticides were used. Production in organic farms conformed to the rules applied in this cultivation 
system (the seed had the Polish ECO certificate). Production in conventional farms followed the rules of the currently recommended intensive methods of cereal cultivation.

\section{Determination of major A- and B-trichotecenes and zearalenone by LC-MS}

Deoxynivalenol (DON), 3-acetyldeoxynivalenol (3-AcDON), the sum of 3acetyldeoxynivalenol and 15-acetyldeoxynivalenol (AcDONs), nivalenol (NIV), fusarenon-X (FUS-X), diacetoxyscirpenol (DAS), HT-2 toxin, T-2 toxin and zearalenone (ZON) were determined by liquid chromatography - triple quadrupole mass spectrometry as described previously by (Berthiller et al. 2005). $10 \mathrm{~g}$ of the ground samples were extracted with $40 \mathrm{~mL}$ acetonitrile/water (84/16, v/v) and purified using MycoSep 227 columns (RomerLabs, Tulln, Austria). $4 \mathrm{~mL}$ of the purified extracts were evaporated to dryness and dissolved in mobile phase (methanol/water 20/80, v/v containing $5 \mathrm{mM}$ ammonium acetate). An Agilent (Waldbronn, Germany) 1100 HPLC system was used in conjunction to a QTrap MS/MS from Applied Biosystems (Foster City, USA). Atmospheric pressure chemical ionisation was used in negative mode for B-trichothecenes and in positive mode for A-trichothecenes. $25 \mu 1$ were injected onto a Thermo Aquasil RP-C18 column $(4.6 \times 100 \mathrm{~mm}, 3 \mu \mathrm{m})$, thermostated to $30^{\circ} \mathrm{C}$. The multiple reaction monitoring mode was used for quantification of the samples. This method was carefully optimized for the quantification of selected Fusarium mycotoxins in cereal. Its limits of quanitification (LOQs) are $3 \mu \mathrm{g} / \mathrm{kg}$ DON, $13 \mu \mathrm{g} / \mathrm{kg} 3-\mathrm{AcDON}, 4 \mu \mathrm{g} / \mathrm{kg}$ AcDONs, $18 \mu \mathrm{g} / \mathrm{kg}$ NIV, $6 \mu \mathrm{g} / \mathrm{kg}$ FUS-X, $1 \mu \mathrm{g} / \mathrm{kg}$ DAS, $4 \mu \mathrm{g} / \mathrm{kg}$ HT- $2,1 \mu \mathrm{g} / \mathrm{kg}$ T-2 and 3 $\mu \mathrm{g} / \mathrm{kg}$ ZON. The limits of detection (LODs) were about 3 times lower than the LOQs.

\section{Determination of ergosterol}

Samples containing $100 \mathrm{mg}$ of ground grains were placed into $17 \mathrm{~mL}$ culture tubes, suspended in $2 \mathrm{~mL}$ of methanol, treated with $0.5 \mathrm{ml}$ of $2 \mathrm{M}$ aqueous sodium hydroxide and tightly sealed. Then the culture tubes were placed within $250 \mathrm{~mL}$ plastic bottles, tightly sealed and placed inside the microwave oven (Model AVM 401/1WH, Whirlpool, Sweden) operating at $2450 \mathrm{MHz}$ and $900 \mathrm{~W}$ maximum output. Samples were irradiated (370 W) for 20 s. and after ca. $5 \mathrm{~min}$. an additional $20 \mathrm{~s}$. After $15 \mathrm{~min}$ contents of culture tubes were neutralized with $1 \mathrm{M}$ aqueous hydrochloric acid, $2 \mathrm{~mL} \mathrm{MeOH}$ were added and extraction with pentane $(3 \mathrm{x} 4 \mathrm{~mL})$ were carried out within the culture tubes. The combined pentane extracts were evaporated to dryness in a nitrogen stream. Prior to analysis samples were dissolved in 4 $\mathrm{mL}$ of $\mathrm{MeOH}$, filtered through $13 \mathrm{~mm}$ syringe filters with $0.5 \mu \mathrm{m}$ pore diameter (Fluoropore 
Membrane Filters, Millipore, Ireland) and evaporated to dryness into $\mathrm{N}_{2}$ stream. The sample extract was dissolved in $1 \mathrm{~mL}$ of $\mathrm{MeOH}$ and $50 \mu \mathrm{L}$ was analysed by HPLC technique. Separation was achieved on 150 x $3.9 \mathrm{~mm}$ Nova Pak C-18, $4 \mu \mathrm{m}$ column and eluted with methanol/acetonitrile (90:10) at a flow rate of $0.6 \mathrm{~mL} / \mathrm{min}$. Ergosterol was detected with Waters 486 Tunable Absorbance Detector set at $282 \mathrm{~nm}$. Quantification of ERG was made by a comparison of peak areas with those of external standards of ERG. Confirmation of ERG was achieved by a comparison of retention times with the external standard and by coinjection every tenth sample with an ergosterol standard.

\section{Determination of trichodiene}

Volatile metabolites were extracted from grain using solid phase microextraction method (SPME). Grain samples ( $8 \mathrm{~g}$ ) were placed in $20 \mathrm{~mL}$ vials and extracted by means of headspace SPME during $30 \mathrm{~min}$ at $40^{\circ} \mathrm{C}$ with $100 \mu \mathrm{m}$ polydimethylsiloxane (PDMS) fibre. The analyses were run on a gas chromatograph mass spectrometer (Hewlett Packard GC 6890, MS $5972 \mathrm{~A})$, using an HP - 5MS (0.25 mm x $30 \mathrm{~m})$ capillary column. The injection port temperature was $250^{\circ} \mathrm{C}$, the transfer line temperature was $280^{\circ} \mathrm{C}$ and the analyses were performed with programmed temperature: initial temperature $40^{\circ} \mathrm{C}$ hold $3 \mathrm{~min}$, from $40^{\circ} \mathrm{C}$ $200^{\circ} \mathrm{C}$ at $10^{\circ} \mathrm{C} / \mathrm{min}, 200^{\circ} \mathrm{C}-280^{\circ} \mathrm{C}$ at $20^{\circ} \mathrm{C} / \mathrm{min}$, the final temperature being maintained for 3 min. The helium flow rate was held constant at $0.7 \mathrm{~mL} / \mathrm{min}$. Quantitative analysis of trichodiene was performed in selected ion monitoring (SIM) mode, using following ions for trichodiene detection: $\mathrm{m} / \mathrm{z}$ 67, 93, 108, 109. The amount of trichodiene was estimated comparing the area of its total ion current (TIC) peak with internal standard (tridecane, $25 \mathrm{ng}$ in pentane) and expressed as their ratio (RU). Trichodiene was identified by comparing its mass spectrum with literature data (Jeleń et al. 1995).

\section{Determination of ATP}

Adenosine-5' - triphosphate (ATP) measurement was carried out using luciferase enzyme. ATP was extracted from $1.00 \mathrm{~g}$ grain samples using $8 \mathrm{~mL}$ boiling Tris buffer $(0.1$ molar solution, $\mathrm{pH}-7.75) .100 \mu \mathrm{L}$ of this extract were mixed with $100 \mu \mathrm{L}$ reagent containing luciferin and luciferase (LuminATE (QM), Celsis, Netherlands). The emitted light was quantified by Lumac Biocounter M 1500 luminometer and readout as Relative Light Units (RLU). The emitted light correlates with the amount of ATP in the sample. 


\section{Statistical analyses}

The significance of differences in mean values was evaluated with the use of Student's $t$-test, and linear correlation analysis was made for all studied parameters.

\section{Results and discussion}

The wheat grain samples classified into 4 different groups (CON I, CON II, CON III and ECO) markedly differed in the analysed parameters: HT-2 toxin, DON, 3-AcDON, NIV, sum of the most important group B trichothecenes in grain (DON+NIV together), ERG, TRICH, ATP and seed vigour parameters (non-germinated and abnormally germinated grains as well as grains with Fusarium mycelium). The results are presented in Tables 1 and 2 (except of ZEA concentrations because their were below the limit of detection).

The grains were characterized by a low proportion of infestation by fungi of the genus Fusarium, ranging from 0 to $4.0 \%$, but differences between the groups were not significant. The proportion of grains with Fusarium mycelium was positively correlated with the proportion of abnormally germinated grains, although value of Pearson correlation coefficient was not significant, because during vegetation Fusarium is not the only factor influencing abnormal grain germination, but also harvest conditions, kernel damage as well as preinfestation changes. Additionally, since these were productive farms, an accurate determination of the above mentioned factors was difficult. A significant correlation was found between the proportion of non-germinated grains and the proportion of abnormally germinated grains. Mean values of both these parameters were the lowest in CON I, and the highest in ECO. 
The mean concentration of trichothecene toxins in CON I and CON II can be regarded as low, and it is comparable with results reported by (Pettersson 1996, Perkowski et al. 1997). In those groups, NIV+DON concentration reached $43.0 \mu \mathrm{g} \mathrm{kg}^{-1}$ (CON I) and $30.0 \mu \mathrm{g} \mathrm{kg}^{-1}$ (CON II). In organically grown wheat, the NIV+DON level was similar, but the concentration of DON was higher than the concentration of NIV. In comparison with CON I, CON II and ECO, significant differences were found in CON III (conventional but lacking chemical protection), where NIV+DON content was over 14 times higher than the mean for the other groups $\left(635.2 \mu \mathrm{g} \mathrm{kg}^{-1}\right.$ versus $\left.44.3 \mu \mathrm{g} \mathrm{kg}^{-1}\right)$, and the major contributor was DON.

Concentrations of trichodiene (TRICH), which is a precursor of trichothecenes (Jelen et al. 1995), were the highest in samples containing the highest levels of trichothecenes (CON III), while the lowest in organically grown wheat seed. A positive correlation $(\mathrm{r}=0.788, \mathrm{P}=0.05)$ was observed between TRICH level and concentration of NIV+DON in seed.

In this study, with the use of so wide-ranging wheat materials, concentrations of ERG (ergosterol, indicator of fungal biomass) and ATP (indicator of microbial biomass in the outer parts of the grain) were measured. To be exact, Reid et al. (1999) examined disease severity, ergosterol content, fungal DNA content and mycotoxin (DON and fumonisin $\mathrm{B}_{1}$ ) concentration in silk maize ears channel-inoculated with $F$. graminearum and $F$. moniliforme. The authors reported that although biomass may be the best predictor of disease ratings, the DNA analysis demonstrated that this biomass was not always produced by the expected Fusarium sp. However, the above experiments were carried out for maize. Similar conclusions were indicated by Marfleet et al. (1991) as well.

The highest ERG level was $2.39 \mathrm{mg} / \mathrm{kg}$ (CON III), but it reached a similar value in ECO. These values were significantly higher than in CON I and CON II, but still were below the threshold of $3 \mathrm{mg} / \mathrm{kg}$ reported by Schnürer (Schnürer and Jonsson 1992) for seed showing no symptoms of fungal colonization. In CON I, the lowest ERG level was recorded, and ATP content was also low (2153 RLU). It is interesting that such a low ATP concentration was recorded in all analysed samples of this group. This value was about 8-fold lower than in organically grown wheat seed (16128 RLU). It is probably a result of the lack of chemical protection in organic farming, which is favourable for microbial growth in the outer parts of the grain. The lack of chemical protection and high mineral fertilization combined with all other agronomic practices used in conventional cultivation in CON III could favour fungal 
growth at the expense of other microorganisms. This was reflected in a high ERG and mycotoxins concentration and relatively low ATP content. Because of the varied cultivation systems, only a low positive correlation between ERG and ATP content was found when all four groups were analysed jointly. When the groups were analysed separately, the highest correlation between these characters $(r=0.726$, significant at $\mathrm{P}<0.01)$ was recorded in $\mathrm{CON} \mathrm{I}$, which seems to be the most common in that part of Poland.

In conclusion, results of this study show that wheat seed in north-eastern Poland in 2003 was characterized by a low level of colonization by fungi of the genus Fusarium, but considerable differences were observed depending on cultivation system. Seed samples from organic farms contained similar amounts of Fusarium toxins but higher levels of ERG and ATP than conventionally grown and chemically protected seed samples did. A slightly higher DON content in ECO samples in comparison to CON II samples, and especially CON I samples, and a very low NIV content suggest that while observing the principles of organic farming, especially appropriate crop rotation, the absence of chemical protection does not necessarily have to led to increased concentrations of these metabolites in grain, which was also emphasized by Champeil et al. (2004). At the conventional cultivation system cereals, especially wheat and maize, account for a very large share of crops in crop rotation. Necrotrophic pathogens from genus Fusarium develop dynamically on post-harvest residue of these crops, which promotes the accumulation of FHB symptoms in the successive years, especially in wheat following maize. Dill-Macky and Jones (2000) reported that in case of wheat grown after soy FHB symptoms occur in a much lesser degree. The application of ploughing additionally limits the incidence of this disease, as post-harvest residue is transferred to deeper soil layers. Thus it seems that the application of an appropriate crop rotation scheme in organic farming (with papilionaceous plants), together with comprehensive mechanical soil cultivation reduces the risk of pathogenic species from genus Fusarium to such an extent that a lack of chemical protection does not have a significant effect on an increase of Fusarium toxin concentrations in wheat kernels. It is possible that a significantly higher dry matter content (including that of nutrients and minerals) in tissues of plants grown in the organic farming system (Kouba 2003) is also accompanied by a higher concentration of phytochemical substances exhibiting fungistatic action connected with resistance to fungal pathogens. It is of interest that conventional farming with no fungicides applied (CON III) resulted in a drastic increase of Fusarium toxin concentrations in kernels. This result is especially important in view of the increasingly promoted and implemented sustainable 
cultivation system, in which chemical crop protection is reduced, at the simultaneous maintenance of major elements of the conventional farming system (e.g. the application of mineral fertilizers) and at the same time placing more emphasis on crop rotation and mechanical tillage. The most intensive agronomic practices resulted in significantly lower concentrations of ERG, ATP and TRICH, as compared to the other systems of cultivation. The highest levels of ergosterol were detected in samples from conventional cultivation lacking chemical protection. These results form the basis for further research on this subject.

\section{Acknowledgments}

This work was realized within a programme of Austrian-Polish scientific and technical cooperation no. $7 / 2004$.

\section{References}

Abramson D, Gan Z, Clear RM, Gilbert J, Marquardt RR. 1998. Relationship among deoxynivalenol, ergosterol and Fusarium exoantigens in Canadian hard and soft wheat. International Journal of Food Microbiology 45: 217-224.

Berthiller F, Schuhmacher R, Buttinger G, Krska R. 2005. Rapid simultaneous determination of major type A- and B-trichothecenes as well as zearalenone in maize by high performance liquid chromatography-tandem mass spectrometry. Journal of Chromatography A 1062: 209_ 216.

Champeil A, Fourbet JF, Doré T, Rossignol L. 2004. Influence of cropping system on Fusarium head blight and mycotoxin levels in winter wheat. Crop Protection 23: 531-537.

Dill-Macky R., Jones R. K. 2000. The Effect of Previous Crop Residues and Tillage on Fusarium Head Blight of Wheat. Plant Disease 84: 71-76.

Ekblad A, Wallander H, Näsholm T. 1998. Chitin and ergosterol combined to measure total and living fungal biomass in ectomycorrhizas. New Phytologist 138: 143-149. 
Elmholta S, Labouriau R. 2005. Fungi in Danish soils under organic and conventional farming. Agriculture, Ecosystems and Environment 107: 65-73.

Eudes F, Collin J, Rioux S, Comeau A. 1997. The trichothecenes, a major component of wheat scab pathogenesis. Cereal Research Communication 25: 495-496.

Grodzińska K, Szarek-Łukaszewska G, Godzik B. 1999. Survey of heavy metal deposition in Poland using mosses as indicators. The Science of the Total Environment 229: 41-51.

Hampton JG, Tekrony DM. 1995. Handbook of vigour test methods. 3rd EditionZurich: ISTA.

Jeleń H, Mirocha C, Wąsowicz E, Kamiński E. 1995. Production of volatile sesquiterpenes by Fusarium sambucinum strains with different abilities to synthesize trichothecenes. Applied and Environmental Microbiology 61: 3815-3820.

Kouba M. 2005. Quality of organic animal products. Livestock Production Science 80: 33-40 Lemmens M, Haim K, Lew H, Ruckenbauer P. 2004. The effect of nitrogen fertilization on Fusarium head blight development and deoxynivalenol contamination in wheat. Journal of Phytopathology 152: 1-8.

Łukanowski A, Sadowski Cz. 2002. Occurrence of Fusarium on grain and Hades of Winter wheat cultivated in orgnic, integrated, conventional systems and monoculture. Journal of Applied Genetics 43A: 69-74.

Malmauret L, Parent-Massin D, Hardy JL. 2002. Contaminants in organic and conventional foodstuffs in France. Food Additives and Contaminants 19: 524-532.

Marfleet L, Magan N, Lacey J. 1991. The relationship between fungal biomass, ergosterol and grain spoilage. In Proceedings of the 5th International Working Conference on Stored Product Protection (ed. F. Fleurat-Lessard \& P. Ducom), pp 405-412. INRA: Bordeaux, France. 
Packa D, Koczowska I. 1987. The effect of Fusarium culmorum and Fusarium nivale metabolites on germination, seedling growth and cytological disturbances of rye, wheat and triticale. Mycotoxin Research, Special Edition. European Seminar, "Fusarium-, mycotoxins, taxonomy, pathogenicity: 82-85.

Perkowski J, Stachowiak J, Kiecana I, Goliński P, Chełkowski J. 1997. Natural occurrence of Fusarium mycotoxins in Polish cereals. Cereal Research Communication 25: 379-380.

Perkowski J, Chełkowski J, Goliński P. 2004. Occurrence of mycotoxins in cereals, plants, foods and feeds in Poland. In: An overview on toxigenic fungi and mycotoxins in Europe. Pettersson H. 1996. Mycotoxins in Scandinavian cereals; 1996; Poland Bydgoszcz: Mikotoksyny w żywności, surowcach i paszach przemysłowych: 14-20.

Pussemier L, Larondelle Y, Van Peteghem C, Huyghebaert A. 2006. Chemical safety of conventionally and organically produced foodstuffs: a tentative comparison under Belgian conditions. Food Control 17: 14-21.

Reid LM, Nicol RW, Ouellet T, Savard M, Miller JD, Young JC, Stewart DW, Schaafsma AW. 1999. Interaction of Fusarium graminearum and F. moniliforme in maize ears: disease progress, fungal biomass, and mycotoxin accumulation. Phytopathology Vol. 89, No. 11: 1028-1037.

Schnürer J, Jonsson A. 1992. Ergosterol levels and mould colony forming units in Swedish grain of food and feed grade. Acta Agriculturae Scandinavica Section B-Soil and Plant Science 42: 240-245.

Teich AH. 1989. Epidemiology of wheat (Triticum aestivum L.) scab caused by Fusarium spp. In: Fusarium - Mycotoxins, Taxonomy and Pathogenicity, Chełkowski J, editor. Amsterdam: Elsevier. pp199-225.

Williams AP. 1989. Methodological developments in food mycology. Journal of Applied Bacteriology Symposium Supplement: 61-67. 
Table 1. Concentration of trichothecenes $\left(\mu \mathrm{g} \mathrm{kg}^{-1}\right)$ and ergosterol (ERG, $\mathrm{mg} \mathrm{kg}^{-1}$ ) and amount of trichodiene (TRICH), adenosine triphosphate (ATP) and vigour test parameters for 32 examined wheat grain samples obtained from different cultivation systems.

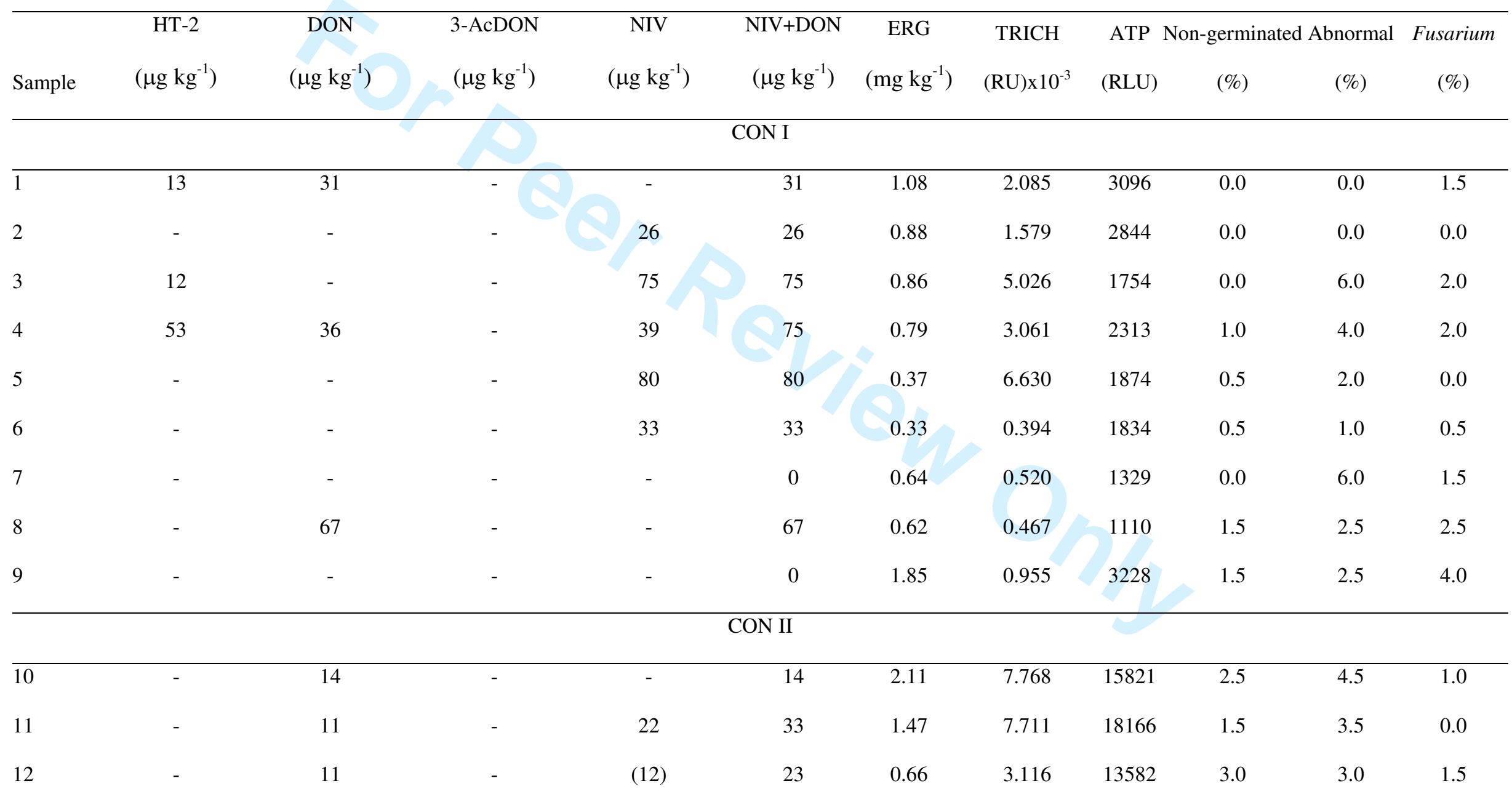




\begin{tabular}{|c|c|c|c|c|c|c|c|c|c|c|c|}
\hline 13 & 4 & 26 & - & - & 26 & 0.79 & 3.649 & 16199 & 4.5 & 7.0 & 1.5 \\
\hline 14 & 6 & 53 & - & (13) & 66 & 0.55 & 1.319 & 12706 & 3.5 & 4.5 & 0.5 \\
\hline 15 & - & 17 & - & - & 17 & 0.46 & 2.385 & 17262 & 6.0 & 8.0 & 3.5 \\
\hline \multicolumn{12}{|c|}{ CON III } \\
\hline 16 & - & 784 & 18 & 27 & 811 & 1.83 & 6.293 & 16642 & 2.0 & 4.5 & 0.0 \\
\hline 17 & - & 480 & - & 43 & 523 & 2.9 & 3.961 & 14893 & 3.0 & 2.5 & 2.0 \\
\hline 18 & 66 & 607 & 19 & (7) & 614 & 2.01 & 7.866 & 10944 & 1.5 & 3.0 & 0.5 \\
\hline 19 & - & 190 & - & - & 190 & 3.34 & 8.581 & 5663 & 4.0 & 1.0 & 1.5 \\
\hline 20 & - & 997 & 37 & 41 & 1038 & 1.87 & 3.285 & 10009 & 1.5 & 1.5 & 0.0 \\
\hline \multicolumn{12}{|c|}{ ECO } \\
\hline$\overline{21}$ & - & - & - & 28 & 28 & 3.34 & 1.528 & 10010 & 2.0 & 6.5 & 5.0 \\
\hline 22 & 8 & - & - & 13 & 16 & 3.26 & 1.262 & 10477 & 3.5 & 3.5 & 2.5 \\
\hline 23 & - & - & - & - & 0 & 2.01 & 1.404 & 12740 & 4.5 & 9.5 & 2.0 \\
\hline 24 & - & 380 & - & - & 380 & 2.95 & 4.843 & 9772 & 2.5 & 10.5 & 1.5 \\
\hline 25 & - & 12 & - & - & 12 & 1.65 & 0.644 & 15843 & 4.5 & 9.5 & 2.0 \\
\hline 26 & - & - & - & - & 0 & 2.44 & 0.799 & 14828 & 3.5 & 7.5 & 1.5 \\
\hline 27 & - & 7 & - & - & 7 & 0.92 & 2.009 & 14287 & 2.5 & 7.0 & 3.5 \\
\hline 28 & - & 60 & - & - & 60 & 2.88 & 0.472 & 22062 & 10.5 & 7.5 & 1.0 \\
\hline 29 & - & - & 181 & - & 0 & 2.84 & 1.410 & 31273 & 3.5 & 2.0 & 0.5 \\
\hline
\end{tabular}




$\begin{array}{rrrrrrrrrrrr}30 & - & - & - & - & 0 & 2.66 & 0.501 & 18701 & 3.5 & 2.5 & 0.0 \\ 31 & - & - & - & - & 0 & 1.67 & 0.943 & 23831 & 3.5 & 4.0 & 3.0 \\ 32 & - & 16 & - & - & 16 & 1.39 & 0.753 & 9714 & 0.5 & 3.0 & 2.5\end{array}$

$\mathrm{T}-2$, DAS were not detected in the samples (LOQ: $1 \mu \mathrm{g} / \mathrm{kg}$ )

FUS-X was detected only in sample 15 at $12 \mu \mathrm{g} / \mathrm{kg}$ (LOQ: $6 \mu \mathrm{g} / \mathrm{kg}$ )

“_" means that no peak was found

Results in brackets are below the limit of quantitation 
Table 2. Mean values of analysed characters in wheat seed samples from four cultivation systems

\begin{tabular}{|c|c|c|c|c|c|c|c|c|c|c|c|}
\hline \multirow{3}{*}{$\begin{array}{l}\text { Cultivation } \\
\text { System }\end{array}$} & \multicolumn{5}{|c|}{ Mycotoxins $\left(\mu \mathrm{g} \mathrm{kg}^{-1}\right)$} & \multirow{3}{*}{$\begin{array}{c}\text { TRICH } \\
(\mathrm{RU}) \times 10^{-3}\end{array}$} & \multirow{3}{*}{$\begin{array}{c}\text { ERG } \\
\left(\mathrm{mg} \mathrm{kg}^{-1}\right)\end{array}$} & \multirow{3}{*}{$\begin{array}{c}\text { ATP } \\
\text { (RLU) }\end{array}$} & \multicolumn{3}{|c|}{ Proportion of grains (\%) } \\
\hline & \multirow[b]{2}{*}{ HT-2 } & \multirow[b]{2}{*}{ DON } & \multirow[b]{2}{*}{ 3-Ac DON } & \multirow[b]{2}{*}{ NIV } & \multirow{2}{*}{$\begin{array}{l}\text { NIV+ } \\
\text { DON }\end{array}$} & & & & & & Fusarium \\
\hline & & & & & & & & & Non-germ. & Abnorm. germ. & mycelium \\
\hline $\mathrm{CON} \mathrm{I}$ & 8.7 & $14.9^{\mathrm{a}}$ & $0.0^{\mathrm{a}}$ & $28.1^{\mathrm{b}}$ & $43.0^{\mathrm{b}}$ & $2.302^{\mathrm{a}}$ & $0.82^{\mathrm{a}}$ & $2153^{\mathrm{a}}$ & $0.6^{\mathrm{a}}$ & $2.7^{\mathrm{a}}$ & 1.6 \\
\hline CON II & 1.7 & $22.0^{\mathrm{b}}$ & $0.0^{\mathrm{a}}$ & $7.8^{\mathrm{a}}$ & $29.8^{\mathrm{a}}$ & $4.325^{\mathrm{ab}}$ & $1.01^{\mathrm{a}}$ & $15623^{\mathrm{b}}$ & $3.5^{\mathrm{b}}$ & $5.1^{\mathrm{b}}$ & 1.3 \\
\hline CON III & 13.2 & $611.6^{\mathrm{c}}$ & $14.8^{\mathrm{b}}$ & $23.6^{\mathrm{b}}$ & $635.2^{\mathrm{c}}$ & $5.997^{\mathrm{b}}$ & $2.39^{\mathrm{b}}$ & $11630^{\mathrm{b}}$ & $2.4^{\mathrm{b}}$ & $2.5^{\mathrm{a}}$ & 0.8 \\
\hline ECO & 0.7 & $39.8^{\mathrm{b}}$ & $15.3^{\mathrm{b}}$ & $3.4^{\mathrm{a}}$ & $43.3^{b}$ & $1.381^{\mathrm{a}}$ & $2.3^{\mathrm{b}}$ & $16128^{\mathrm{b}}$ & $3.7^{\mathrm{b}}$ & $6.1^{\mathrm{b}}$ & 2.1 \\
\hline
\end{tabular}

${ }^{a, b, c}$-Values marked with the same letters within columns do not differ significantly $(\mathrm{P}>0.05)$. 
Figure 1. Location of sites of seed samples collection on a map of Poland.

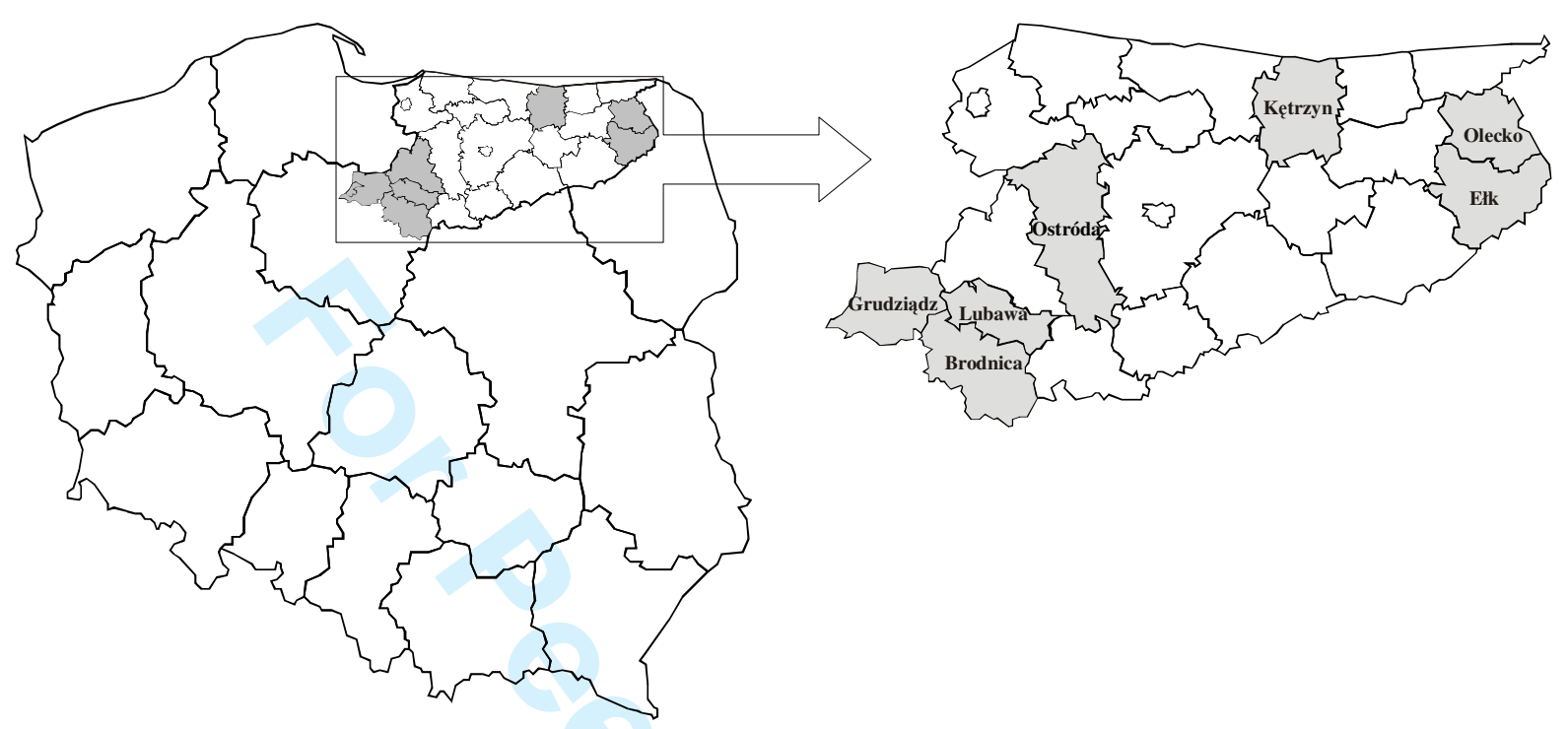

